Transactions of the Royal Asiatic Society of Great Britain and Ireland http://journals.cambridge.org/TRA

Additional services for Transactions of the Royal Asiatic Society of Great Britain and Ireland:

Email alerts: Click here

Subscriptions: Click here

Commercial reprints: Click here

\title{
XI. Some Account of the Ruins of Ahwuz
}

Robert Mignan and Robert Taylor

Transactions of the Royal Asiatic Society of Great Britain and Ireland / Volume 2 / Issue 01 / March 1830, pp 203 - 212
DOI: 10.1017/S0950473700001373, Published online: 19 November 2009

Link to this article: $\underline{\text { http://journals.cambridge.org/abstract_ } \$ 0950473700001373}$

How to cite this article:
Robert Mignan and Robert Taylor (1830). XI. Some Account of the Ruins of Ahwuz. Transactions of the Royal Asiatic Society of Great Britain and Ireland, 2, pp 203-212 doi:10.1017/S0950473700001373

Request Permissions : Click here 
XI. Some Account of the Ruins of AHWUz. By Lieutenant ROEERT MIGNAN, of the First Bombay European Regiment; with Notes by Captain Robert Tayoor, Resident at Bussorah.

Read June 14, 1828.

IT having been my intention for some time to visit a few of the ruined cities whose decay has converted realms into desarts, and strewed the path of the shepherd with fragments of arches and pillars that once arose in majesty over heroic warriors, I set out in September 1826, for the purpose of examining the remains of the once celebrated city of Ahwuz, lying on the banks of the noble river Karun.

As there are only a few ruined villages (unworthy the traveller's and reader's notice) until its immediate vicinity is reached, I shall pass over the time that elapsed during my journey. It is sufficient to state that the whole country is a perfectly flat and uncultivated waste, abandoned by its former inhabitants to rapacious animals, and to still fiercer hordes of wild and ferocious Arabs, who occasionally pitch their flying camps here when in search of pasturage or plunder.

Previous to my quitting Bussorah I procured Kinneir's Geographical Memoir of the Persian Empire (the only book $I$ have seen in our language that attempts any description of Ahwuz), as a guide and for reference.

The modern town of Ahwuz occupies but a small portion of the site of the old city, on the eastern bank of the $\mathbb{K}$ arun, and exhibits a mean and solitary appearance, contrasted with the immense mass of ruin that rears its rugged head behind. Its houses are built entirely of stone brought from the ruins, and it can only boast of one decent building, a mosque, apparently modern. The population at present does not exceed sixteen hundred souls. Considerable traces are discernible of the bund that wals thrown across the river, chiefly, if not entirely, for the purposes of irrigation. A part of the wall is still standing, remarkable for its high state of preserri- 
tion; it is in many places ten feet high, and nearly as much in breadth; while it extends upwards of cne hundred feet in length without any intermediate breach : indeed, on examination, $\mathbb{I}$ found many single blocks of stone in it measuring eight and ten feet. The river dashes over the bund with great violence, and accelerated by a strong current always ruming southwardly with rapidity, is projected into a fall, the sound of which is to be heard from a considerable distance. Boats of every description are obliged to discharge their goous previous to :m attempt at pessing over, and even then the passage is attended with much danger. I understood that they are frequently swamped. The river is one hundred and sixty yards in breadth at each side of the dyke, and of great depth; therefore the shallowness opposite the town is caused by the great mass of masonry below the surface. The remains of this buid are the portions which Kimneir appears to assign to the remnants of the palace of Artainanes. Upon what authority he asserts that any paiace was erected across the river, or that it was the winter residence of Artabaves, the last of the Parthian lings, I am at a loss to discover. Kinneir also mentions that many of the excurations in the rocks bore the exact form and dimensions of a confin : for these sepulchral recesses I looked in vain, although, towards the south ent of the town, there are several singular cavities, and a few vatermills erected between the rocks, the latter probably constructed since his risit.

The remains of a Lridge I found where he places it, namely, behind the town; and here too commences the muss of rums, extending at least ten or twelve miles in a south-casterly direction, while its greatest brealth covers about half that distance. I could not find any person who had been to the end of these ruins; and according to the inhabitants, their extent would occupy a joumey of two months. Alchough this is doubtless an exaggeration, it may be as well to mention, as an hypothesis, that they extcind to the neighbourhood of Ram Hormis.

All the mounds are covered with hewn stone, bunt brick, and pottery. The first which I ascended I found to be nearly two hmondred feet high. In many parts flights of steps are plainly discemible in good preservation, and at the base of this mass of ruins I dug into some graves, and found stones measuring five and six feet in length. Hence it was I brought away several stones with inscriptions upon them in the Cufic character, and others with fret-work, all indicative of an era subseciuent to the Muham- 
medan.* In every direction I met with vast heaps of circular flat stones perforated in the centre, apparently used for the purpose of grinding grain, though rather colossal for such a prippose, as they generally measured four, five, and six feet in diameter, and some exhibited characters upoin them. The above-mentionel mound extends as far as the eye can reach, varying in height and breadth, and is the first in magnitude upon the plain. To the west of this is a mound entirely of stone, fifty feet high and twenty broad: here are sereral flights of steps, which may, without difficulty, be traced to its summit; although they are much mutilated, and injured by exposure to the atmosphere.

About a mile to the east, separated by a deep ravine, stands an inmense pile of materials, consisting of stone, brick, and tile of vilrious colours. The Arabs who accompanied me called it the Kasr $(,-3)$, or palace. Its ascent is gradual but fatiguing, from the numerous furrows which have been apparently worn by water on its passage. The height is, at the lowest estimate, one hundred and fifty feet from the plain below. On the summit are many floorings of stone, as fresh as if only recently liad down; together with several rounded troughs, some of which were of Persepolitan marble in its rough state. From numerous cavities we sturted large flocks of jackals, and I found a number of porcupine quills strewet? in every direction. I discovered that it was impossible to descend on the opposite side, as it was nearly perpendicular, and exhibited many frimhtful chasms. At the base of this mound the camel's thorn (1) is plentiful, and from its green appearance considerably relieved the landscape the general dreariness and sterility of which is gioomy beyond conception. The $K a s r$ is about three miles from the east bank of the river. From this edifice I proceeded to a mound about half a mile distunt in a north-westerly course. Its form was circular, measuring two hundred yards. At its base I traced a wall of masonry for twenty-one feet, the facc of which is perfect and umbroken, and appears to have been the front of some building. The face opposite to that by which I ascended joinanother ruined heap, covered with fragments of glazed tile, a coarse kind of crystal, pieces of alabaster, and bits of glass.

* I believe Cufic coins have also been found in the ruins. I murchised a geld one, hut will not vouch for its having been dug up there: it is nearly one thousand years old, and is as freth in aingearance as if just firom the mint. 
Several mounds form one connected chain of rude, unshapen, flaked rock, lying in such naturally formed strata, that the very thought of any part of the materials having been accumulated by human labour from a distant site is scarcely admissible. The soil on which these ruins rest appears peculiarly soft and sandy; the country does not apparently become rocky until the immediate vicinity of Shuster, and even water-carriage from thence is attended with considerable toil and expense. Yet the height of these mountainous ruins and misshapen masses, induces me to admit the notion that the site was by nature elevated at the time the city was built, although from the flatness of the surrounding country I should be inclined to oppose such a conjecture; more particularly as I never heard of any mountains between the Shut-ul-Arab and the Bucktiani chain (which are to be seen from hence extending from the north-west to the south-east), nor do I believe there is a single hillock. Let me not be supposed to exaggerate when I assert, that these mountains of ruin, irregular, craggy, and in many places inaccessible, rival in appearance those of the Bucktiani chain, and are discernible from them, and for nearly as many miles in an opposite direction.

It is a singular fact, that almost every mound I passed over was strewed with shells of different sorts and sizes. I observed them also on the water's edge along the banks of the Karun; therefore we may suppose that at some former period the river, or more probably canals from it, flowed through the city. Glass of all colours is equally abundant, and the fragments of pottery are remarkably fresh.

Many of the burnt bricks that lie on the surface of the mounds appear to have borne some written character; but exposure to the weather, and probably occasional inundations, caused by the melting snows of the adjacent mountains, have nearly effaced all traces of it; though, as I have already mentioned, the character on the hewn stone is as fresh and plain as if only just from the sculptor's hands. No bitumen was observable on the bricks, which I much regretted, as it would have afforded a strong proof of the antiquity of the spot.* 'The circular perforated stones that I have already alluded to appear in many places to have formed aqueducts, as I followed

\footnotetext{
* I met with a few small intaglios, generally denominated seals, and probably used as such, -imilar to those found at and near Babylon; the villagers assured me they liad procured then wen digging for bricks, which I think is not unlikely.
} 
them for a great distance in successive rows in small dry rivulets; and placed so firmly together, that it would have occupied the labour of several days to have removed any of them. The Arabs are always digging up and removing stones for the purpose of building, yet their expenditure has been nothing when compared to the vast quantities of stone and brick that are scattered about. Probably they have excavated a space of a hundred yards, but certainly to no greater extent: which is a proof how abundant the hewn stone is, for there is not a house in the town built of any other material. I am perfectly convinced that as large a city as any now existing might be erected from the ruins that I saw.* The ruins of Ahwuz extend also for a considerable distance on the west bank of the river in a northerly direction, exhibiting the same appearance as the mounds on the east side; though the former are not to be compared with these in point of magnitude. The bund that was thrown across appears to have nearly connected the city together; but as there is abundant room for conjecture, and much ground for idle supposition, it is better and wiser merely to state what is visible: this I have attempted to do, though perhaps with a feeble pen. Nevertheless, whatever our opinions may be regarding this once famous capital of a flourishing province, we must concur in ranking it lower in point of antiquity than either Persepolis or Susa, to say nothing of the mighty Babylon; or how could we persuade ourselves that Alexander the Great, strict and attentive in observation as enterprizing and successful in war, should have navigated the Karun and have made no mention of the city, when comparatively insignificant towns attracted his notice. I repeat, it is my firm opinion and belief that this city, now one vast heap of ruins, was erected long since the days of the above-named illustrious warrior.

To conclude: it must ever be a subject of deep regret that the difficulty of exploring the remains of any spot of antiquity should be heightened by the passions of a people disposed to turbulence and riot. The desolation which, under the influence of a barbarous government, has for years been advancing over Susiana, one of the finest provinces of the east, whether as to soil and climate, or as to aptitude for commercial intercour'se, irresistibly presses on the mind the mutability of earthly dignity; it made me tremble

\footnotetext{
* I was prevented examining the other mounds, that extend to the verge of the horizon, fiom not being able to procure a horse or a mule, although I offered a large sum for the hire of one ; most likely the Sheikh did not deem it safe, from the disturbed state of the country.
} 
for the future fortunes of my native land, and effectually softened into compassion the disgust I might have entertained for the vicious and degraded people of this wilderness of desolation.

Robert Mignan.

\author{
NOTE S \\ TO THE PRECEDING MEMOIR, \\ $B Y$
}

\title{
CAPTAIN TAYLOR.
}

In forwarding to the Royal Asiatic Society the annexed description of the ruins of the ancient city of Ahwaz, situate ninety-two miles north-east of Bussorah, and forty-eight miles south of Shuster, which has been drawn up by Lieutenant Mignan, who has just returned from visiting them, I have been permitted to append the few remarks I could select on this subject from such Oriental manuscripts in my possession as appeared to be most worthy of confidence. As they are illustrative of a topic hitherto lightly toached, and consequently obscure, they can scarcely fail to interest from their novelty, though they might not fix the attention of the reader, from any great intrinsic importance.

Of the foundation of this city I have it not in my power to assign the date. Its name occurs very early in the annals of Islam. The specimens of its architectural decoration, brought from the ruins by Lieut. Mignan, are decidedly Mosiem, bearing inscriptions in no character but the early Cufic, nor language other than the Arabic: a remark equally applicable to the coins and gems usually found there; with the exception of a few small intaglios on cornelian or oriental onyx, the only evidences of an antiquity more remote than the era of Munamind. All these circumstances would appear to lead to one of two conclusions: either that the remains now seen are those of a city founded by the first khalifs of the Ommiade dynasty, or that additions had been made to the edifices already erected by the Persians on a site older than the epoch of the advance and victories of the adherents of Islam. The zenith, however, of its prosperity was attained under the earlier khalifs of the house of Abís ; nor did it long survive their fall. 
The notice of the earliest date is extracted from the Tohfet-ul-Alem, a modern work, composed for the information, and at the desire of the celebrated Mír Alem of Hydrabad, by Mír Abdul Sulíf, a learned relative, and native of Shuster, the present capital of Susiana; it commences with an excellent general description of the province.

Etymology also favours the view taken above : Ahwaiz as well as Hawaozeh, another town of Khúzistan, the ancient Susiana, are two Arabic forms of one root. The earlier name of the former, according to AbulfedA, in his geographical tables, was Humuzin Shehr, strictly a Persian appellation, a compound too, evidently not of modern date; while the various districts of Khiz (whence Susia or Ciassia) were combined under the common name Alahwáz, and the capital was designated by the Arabic terms Suz-ul-Ahwáz, that is to say, the mart or emporium of Al-Ahwaz, or the districts.

According to SamaAnt, as stated in his Biographical and Genealogical Dictionary, its pristine fame and prosperity no longer existed, any more than its proud palaces, and learned, luxurious, and wealthy citizens, in the middle of the twelfth century of our era.

With the exception perhaps of Sistán, no province of Persia is less known or more worthy of investigation than Khuzistán. To the antiquary particularly it presents many objects of interest, in the ancient remains at Ahwáz, Shuster and Desfúl. It may also put forth the additional claim of possessing the last remnant of the Chaldees and Sabeans, the oldest people upon earth; the last depositaries, not improbably, of the earliest philosophical and theological systems of the human race; though, less fortunately, the originators also of its most complicated mythology and most degrading superstitions. The professors at once of the purest notions of unrevealed godhead; and the source of the impurest heretical leaven which has deformed Judaism, Christianity, or Muhammedanism. A considerable portion of their earliest literature is preserved ; and it is not improbable that, with competent aid, their hitherto mysterious doctrines may be satisfactorily elucidated. I am, fortunately, in possession of their most important works, and of the valuable services of their chief priest: and have already translated some of the most interesting chapters of their Sidda Rabba, or book of scriptures, entitled by the erudite and indefatigable Horbary "Liber Adanni."

"I. The city of Ahwa $z$ is one of the largest cities of the earth; and in " Khuzistan, or indeed in the other kingdoms of the world, few are to be Vol. II. 
“ seen equal to it in size and extent. What are now thick and impervious " woods, were once extensive plantations of sugar-cane. Large vats and " manufactories of sugar were also in existence; and mill-stones and other " implements of the art of the sugar-baker are even now so profusely " scattered over the ancient site, that it is impossible to number them. " During the dynasty of the Abbassides, this city was at the height of its " prosperity. Its extent in breadth is supposed to be forty parasangs, " throughout which ruins and remains of magnificent edifices, baths, " caravans, and mosques, are strewed. Extensive as they may appear, the " inhabitants were always in litigation regarding houses and ground, as " spaces sufficiently open and ample could not be had for their accommo" dation. These khalifs, within whose dominions was comprehended most " of the habitable world, named this city ' the source of food and wealth;"

" the inhabitants of which, in their riches and luxury, excelled the rest of

" the world. "The river of Dizipul, a stream nearly equal in size to that of the " Kuran, enters this latter below Bandi Kír, and here the united waters " are termed ' the river of Ahwaz.' The bund of Ahwaz restrained their " course, so that the waters completely overflowed the land, and not a drop " was lost to the aid of cultivation. The intermediate country was corered " with plantations of sugar-cane; and the sugar was conveyed to every part " of the world, as none of foreign manufacture was then imported into " the territories of Persia or Rúm. Thus the inhabitants became rich and " luxurious, and renowned throughout the earth. As wealth, howerer, is " the parent of pride and insubordination, these wealthy citizens revolted " from the khalifs, until Ali ebn Munanmed, the astrologer, surnamed " ' prince of the Zaugis,' from having recruited his army among the "Zaugis, or Nubian slaves of Khuzistan and Busrah, took the field with a " powerful force, and contended for years against the monarchs of the " house of AввÁs. In the course of these hostilities the people served in " the ranks of one or other of the rival armies, and were stiept away in " numbers by the chances of war; until, in the end, the khalifs triumphed. "The rebellious spirit of the people, however, had so disgusted these " princes, that they ceased to favour or embellish the city; and the remain" ing population, left to itself, fell into private feuds and bickerings. "Anarchy and oppression ensued; the weaker fled, industry ceased, and " with it the usual resort of commercial adventurers, and the production 
" of wealth. The last poor remnant of this numerous, wealthy, and " luxurious people, abandoned in despair their plantations and the other " sources of their riches and destructive pride, and sunk into desolation. "The ruins are covered with heaps of stones and fallen masonry, and " the inhabitants of the small modern town are repaid for their labours in " searching among the ruins, after the periodical falls of rain, by the " discovery of gold and silver coins, medals, and sculptures. Several " gold coins of the Abbassides were shewn to me, while residing at Busrah, " by an old inhabitant of Ahwaz. They have on one side an impression in " the Cufic character, of the usual creed; on the margin of the other, the " names of the four first khalifs ; and in the central field the titles of Alhadir " billah, A.H. 381. Skeletons are also not unfrequently disinterred. The " heat of summer, and of the sammum, is here excessive."-Tolfet-ul-Alem, in vocem Ahraz.

"II. Ahwaz is one of the largest districts of the province of Khuzistan. "Its original name was Hormuzin Shehr. According to the authors of the "Labáb and Mushtauk, the name of the capital of the province is Suz ul"Ahroaz, and that of the province Ahwaz, or Khusistan. The greater part " of the city is now in ruins. It is ninety farsangs from Ispahan."Abulfeda Jagwín-ul Bildan, Clim. 9, Art. 303. Diglat-ul Alrceaz.

"The river of Ahwaz waters the shores of the city in lon. $75^{\circ}$, lat. $31^{\circ}$, " and passes westward to Asker Molram in lon. $76^{\circ}$, lat. $31^{\circ} 15^{\prime}$. It nearly " equals the Tigris in breadth; and its banks are adorned with gardens and " pleasure-houses, and enriched by extensive plantations of sugar-cane, " and other valuable productions of the vegetable kingdom."-Abulfeda, Pref. Jagrín-ul Bildan, ad cap. de pluviis.

"III. Ahwaz, one of the divisions of Khuzistan. It is also the proper " name of all the districts of Khuz collectively; whilst that of the capital " of the present day is Sus-ul-Ahwaz. It is almost forty parasangs from "Busrah, and was one of the cities most celebrated for the numbers, " learning, and wealth of its doctors, divines, merchants, and nobles, " whether natives or foreigners. Most of it is now in ruins, and little " remains but a scanty population, and mounds and hillocks of earth and " masonry, fragments of the former capital."-Samaani Kitab-ul Aunab, in zocem Ahraz.

“ IV. Al Ahwaz. A territory comprizing nine districts, situated between "Busrah and Fars, which are comprehended under the single proper name 
"Al Ahwaz. This is the plural of Húz, which last, however, though it " be the singular form, may not be applied to signify any one of the nine " districts singly. The names of these are as follow : Ram Hormuz, Asker "Mukram, Justar, Jundisahur, Sus, Sunaj, Nabr Jini, Aidaj, and Ma. " nadhir."-Kamas in voce.

Hawaizah signifies a small collection of inhabitants, the diminutive of the root hiz, " people, bodies of men." It is also the name of a town of Susiana, of a date much subsequent to that of the city of Ahwaz; and, like it, raised on the site of a more ancient city.

V. The Persian Dictionary, "Borhani Patáá," under the words Khuz, and Khuzistan, states that these are both names of a country in Persia, of which Shuster is the capital ; and that the first signifies also sugar; and the second, any country productive of the sugar-cane, or a manufactory of this article.

Bussorah, November 24, 1826.

$$
\text { (Signed) Robert Taylor. }
$$

